\title{
IN VIVO USE OF N-BUTYL-2-CYANOACRYLATE IN CLEFT PALATE SURGERY AND A COMPARISON OF ITS EFFICACY WITH SUTURE MATERIAL
}

\author{
IN VIVO MODELDE YARIK DAMAK CERRAHISINDE N-BUTIL-2-SIYANOAKRILATIN \\ KULLANIMI VE ETKINLIĞININ SÜTÜR MATERYALi iLE KARŞILAŞTIRILMASI
}

\author{
Furkan KARABULUT'1 (D), Serhat ÖZBEK² (D) \\ ${ }^{1}$ Kütahya Health Sciences University, Evliya Çelebi Education and Research Hospital, Department of Plastic, Reconstructive and \\ Aeshetic Surgery, Kütahya, Turkey \\ ${ }^{2}$ Bursa Uludağ University, Faculty of Medicine, Department of Plastic and Reconstructive Surgery, Bursa, Turkey
}

ORCID IDs of the authors: F.K.0000-0002-6668-3495; S.Ö.0000-0001-5689-0979

Cite this article as: Karabulut F, Ozbek S. In vivo use of n-butyl-2-cyanoacrylate in cleft palate surgery and a comparison of its efficacy with suture material. J Ist Faculty Med 2021;84(2):197-207. doi: 10.26650/IUITFD.2020.0065

\section{ABSTRACT}

Objective: In this experimental work, we aimed to compare the efficacy of two different methods of combining the mucoperiosteal flaps in an animal model: using a tissue adhesive material $\mathrm{N}$-butyl-2-cyanoacrylate (Glubran®2) and the classical suturing technique in cleft palate surgery.

Methods: Rats were separated into group A and B. In group A $(n=12)$ mucoperiosteal flaps were brought together with absorbable suturing material, while in group $B(n=12)$, adhesive material was used for the same purpose. Palatal mucosa healing was evaluated histologically in terms of inflammatory cell infiltration, fibroblastic activity and vascularization on the postoperative $8^{\text {th }}$ and $16^{\text {th }}$ days.

Results: As a result of this experimental study, there were no differences macroscopically in palatal mucosa healing in both groups. Histologically, on day 8 , the inflammation severity was higher in the suture material group and the difference was statistically significant. On day 16 , fibroblastic activity was significantly lower in the suture material group. There was no significant difference between the groups in terms of vascularity.

Conclusion: As a result of these findings, Glubran ${ }^{\circledR} 2$ was found to be easily usable and effective with low complication rates, moreover, it was a practical tissue adhesive material for merging mucosal flaps in the midline of the palate.

Keywords: Cyanoacrylate, suture, cleft palate

\section{ÖZET}

Amaç: Bu deneysel çalışma, mukozal yapılarda etkili olan bir çeşit doku yapıştırıcısı olan N-butil-2-siyanoakrilatın (Glubran®2) hayvan modelinde damak onarımında etkinliğini kanıtlamak ve damak mukoza iyileşmesinde sütür materyali ile bu yapıştırıcının etkinliğini karşılaştırmak amacıyla yapılmıştır.

Gereç ve Yöntem: Sıçanlar iki ana gruba ayrıldı. Grup A'da $(n=12)$ mukoperiosteal flepler sütür materyali ile bir araya getirilirken, grup B'de ( $n=12)$ mukoperiosteal flepler doku yapıştırıcı ile biraraya getirildi. Damak mukoza iyileşmesi, histolojik olarak, inflamatuar hücre infiltrasyonu, fibroblastik aktivite ve vaskülarizasyona bakılarak, postop 8. gün ve 16. günde değerlendirildi.

Bulgular: Bu çalışmanın sonucunda; dikiş materyaliyle doku yapıştırıcısı arasında makroskobik bir fark saptanamamıştır. Histolojik olarak, 8. günde, dikiş grubunda inflamasyon şiddetinin istatistiksel olarak anlamlı şekilde yüksek olduğu görüldü. Dikiş grubunda 16. günde, fibroblastik aktivitenin istatistiksel olarak anlamlı miktarda düşük olduğu görüldü. Vaskülarite açısından, iki grup arasında benzer değerler görüldü.

Sonuç: Bu bulgular neticesinde, N-butil-2 siyanoakrilat'ın yarık damak cerrahisinde, mukozal fleplerin orta hatta tespitinde (sütür tekniklerinin uygulanması zor olan bu dar cerrahi sahada) kolay uygulanabilen, etkin ve komplikasyon oranı düşük, cerrah açısından zaman kaybı yaratmayacak bir materyal olabileceği sonucuna varıldı.

Anahtar Kelimeler: Siyanoakrilat, sütür, yarık damak

Corresponding author/iletişim kurulacak yazar: drfurkankarbulut@gmail.com

Submitted/Başvuru: 10.05.2020 • Revision Requested/Revizyon Talebi: 17.09.2020 •

Last Revision Received/Son Revizyon: 25.12.2020 • Accepted/Kabul: 03.01.2021 • Published Online/Online Yayın: 01.04 .2021 


\section{INTRODUCTION}

The palate consists of two major parts, the soft and hard palate, which separate the oral cavity from the nasal cavity. In cleft palate patients, the deficiency of mucosa and bone tissue in the hard palate is the main pathology, while the lack of mucosal tissue in the soft palate is accompanied by velar muscle insufficiency (1).

Palate cleft repair can be grouped in two stages anatomically and functionally. Anatomic repair aims to guide proper maxilla development and to create an adequate nasal base. It aims to provide functional repair, mobile soft palate and velopharyngeal competence. The objectives of cleft palate surgery are normal speech, closure of anatomical defect, correction of dentoalveolar deformity, and reduction of growth retardation of maxillary bone. The success of cleft palate surgery depends on four variables. These are the type of cleft, the experience of the surgeon, the technique applied and the timing of the surgery (2).

Simple palate repair is performed by medializing the mucoperiosteal flaps prepared from cleft edges and suturing together in the midline. In palate surgery, the anatomical location of the palate in the narrow and deep region makes it especially difficult to suture the flaps. Abnormal haemorrhages and tissue necrosis due to trauma to the flaps during the suturing process (which is one of the most difficult parts of the palate surgery), adversely affect wound healing. The defect in wound healing causes complications such as infectious discharge and fistula in the postoperative period. Therefore, N-butyl-2-cyanoacrylate, which has proven its efficacy on mucosal surfaces and has an adhesive and haemostatic effect on tissues, can be used as an alternative to suture materials to prevent complications that may occur during palate surgery (3).

\section{MATERIAL AND METHOD}

\section{Subjects}

Twenty-four female Sprague Dawley rats weighing between 200-300 grams were obtained from Uludağ University Experimental Animals Application and Research Centre. The subjects were followed up in single rat cages for 12 hours in light, 12 hours in darkness, 65\% ( \pm 5$)$ humidity at $21( \pm 3)^{\circ} \mathrm{C}$, post-operative 7 days of non-granulated aqueous food followed by standard rat feed. The study was carried out in Uludağ University Laboratory of Experimental Animals Breeding Application and Research Centre by the decision of the Local Ethics Committee of Animal Experiments of Uludağ University dated 08.02.2018 and numbered 2018-02/02.

\section{Experimental groups}

Twenty-four subjects were divided into 2 groups. Following creation of the cleft by tissue excision, bilateral mucoperiosteal flaps were combined with sutures $(n=12)$ in group A. In group B, bilateral mucoperiosteal flaps were combined with tissue adhesive $(n=12)$. Each group was divided into two subgroups. These subgroups were sacrificed using the cervical dislocation method on the postoperative $8^{\text {th }}$ and $16^{\text {th }}$ days. Twenty-four preserved palate tissues from all subjects were fixed with formalin, in order to compare wound healing under the light microscope.

\section{Preoperative preparation and anaesthesia}

Ketamine hydrochloride (Ketalar, Pfizer, $40 \mathrm{mg} / \mathrm{kg}$ dose) and xylazine (Rompun, Bayer, $5 \mathrm{mg} / \mathrm{kg}$ ) were administered intramuscularly for anaesthesia. During the experiment, if necessary, a maintenance dose was given at the rate of half of the initial dose. Sterile drapes were applied to the surgical site which was cleaned with an antiseptic solution.

\section{Surgical technique}

Following general anaesthesia, the subjects were placed in the supine position, the mouth was opened with the help of a retractor, and the palate was exposed. A headlamp and 6X magnification loupe were used for better evaluation of the surgical site. The soft tissue to be removed from the midline of the palate was marked with a pen (Figure 1). In all subjects, a tissue of $2 \mathrm{~mm}$ in thickness was excised and a defect was created in the standard palatal midline. Bilateral mucoperiosteal flaps were prepared on both sides of the defect starting from the incisive papilla through the last molar tooth (Figure 2). While the flaps were raised, both large palatine arteries were visualized and preserved. In group $A$, the flaps were sutured with 6-0 polydioxanone (PDS) (Figure 3a). In Group B, the flaps were attached to each other using tissue glue (Figure $3 \mathrm{~b}$ ). An Ethicon brand 6-0 round needle PDS was used as a suturing material in this study.

\section{Histopathologic study}

Half of the rats were sacrificed on the $8^{\text {th }}$ day and the other half on the $16^{\text {th }}$ day. Samples taken without deteriorating the integrity of the palate were kept in $10 \%$

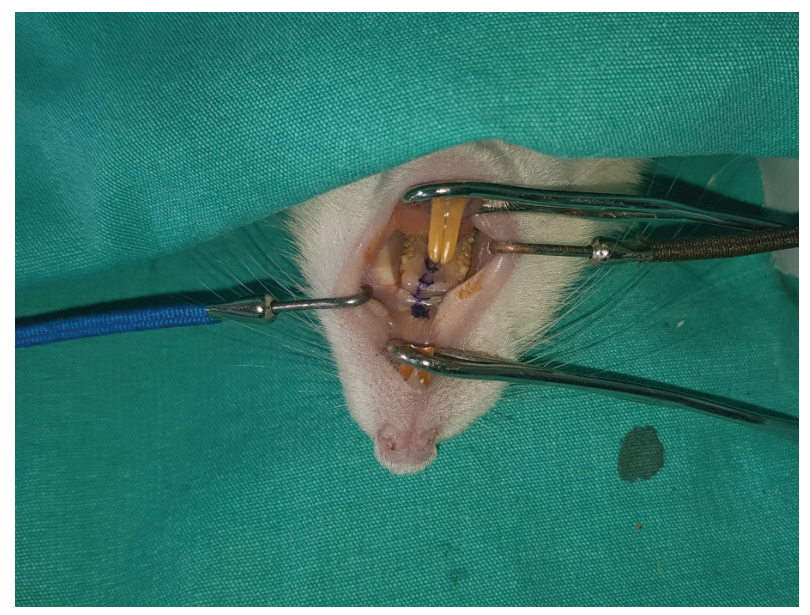

Figure 1: Drawing of the excision site 


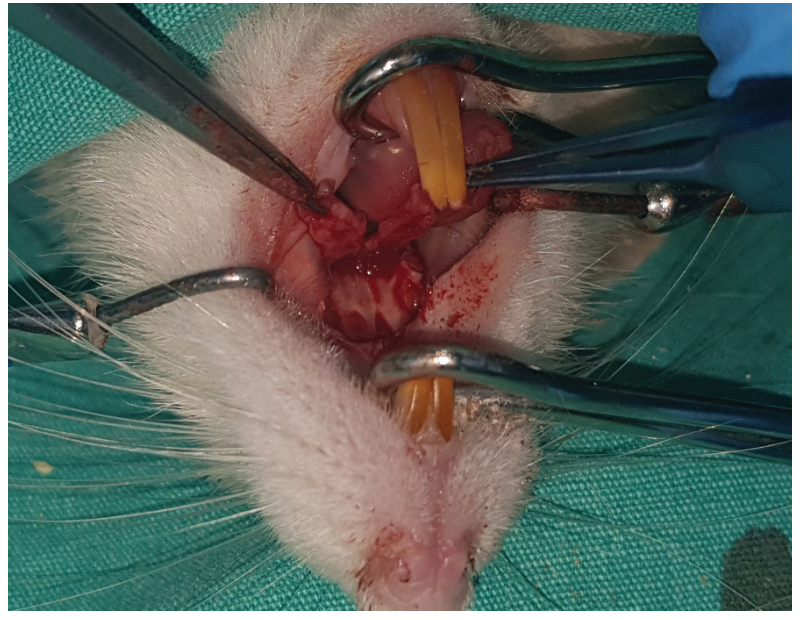

Figure 2: Preparation of mucoperiosteal flaps
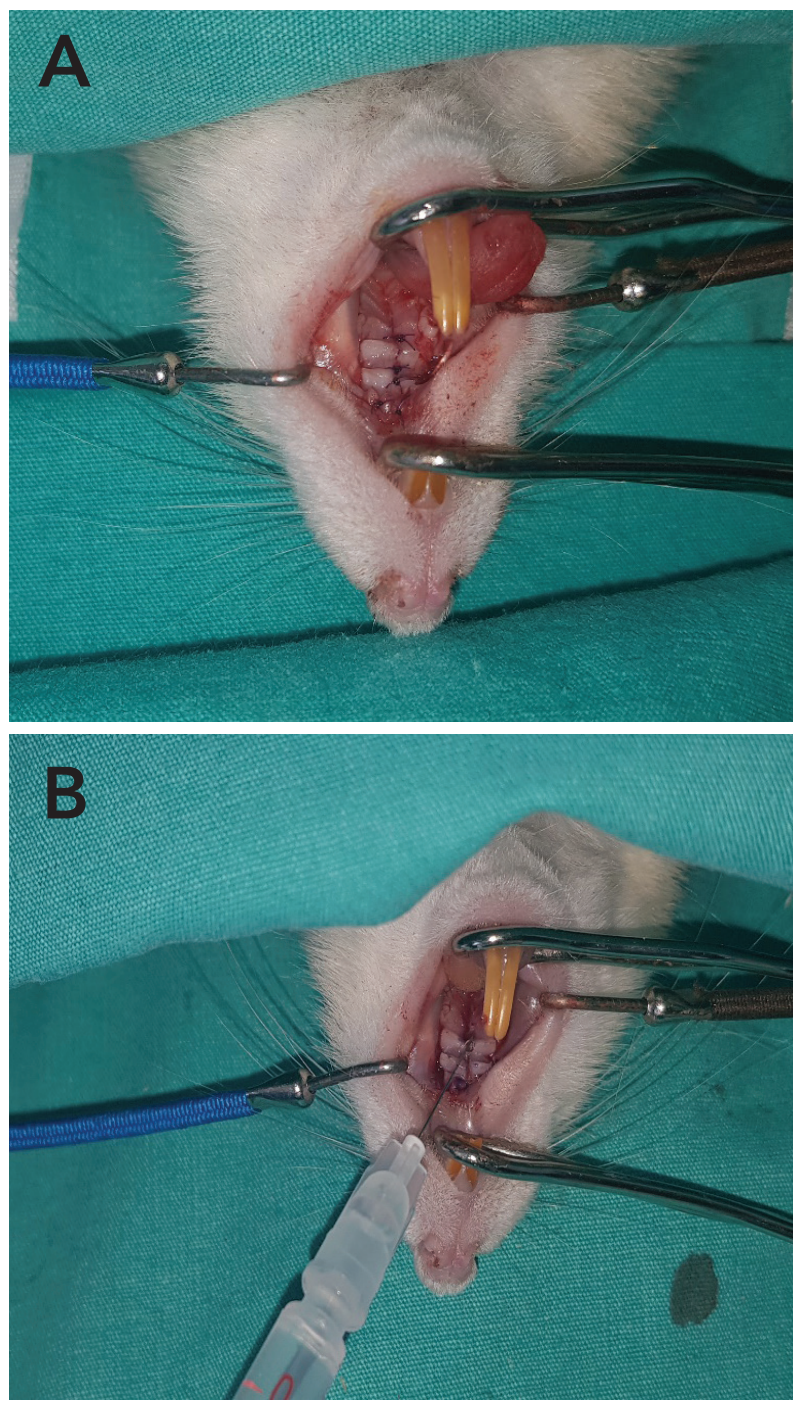

Figure 3: Suturing of mucoperiosteal flaps in group $A$ and application of tissue adhesive group $B$ formaldehyde solution. After the formation of paraffin blocks, longitudinal sections of 2-3 micron in thickness were taken and stained with hematoxylin-eosin and masson trichrome. Histopathological changes in the palatal mucosa were evaluated by the same pathologist under 10X and 40X magnification with light microscopy. Vascularity, inflammatory cell infiltration and fibroblastic activity parameters were examined histopathologically, as described in previous studies (4). In the histopathological examinations, each parameter was divided into classes.

1. Inflammatory Cell Infiltration: 0-None 1-Mild 2-Moderate 3-Severe

2. Vascularity: 0-Insufficient 1-Sufficient 2-Rich

3. Fibroblastic activity: 0-None 1-Mild 2-Moderate 3-Dense

\section{Statistical evaluation}

Mean, standard deviation, median lowest, highest, frequency and ratio values were used in descriptive statistics of the data. The distribution of variables was measured by the Kolmogorov Smirnov test. The Mann-Whitney U test was used for the analysis of quantitative independent data. The SPSS 22.0 program was used during the analyses.

\section{RESULTS}

\section{Macroscopic results}

Macroscopically, a randomly selected rat palate from group A and group B was evaluated on the postoperative $1^{\text {st }}$ and $4^{\text {th }}$ days. All of the subgroups were evaluated on the eighth and sixteenth days. We evaluated the presence of necrosis in mucoperiosteal flaps, exudate accumulation, wound healing and infection. In all evaluations, the surgical site was photographed for macroscopic comparison.

There was no macroscopic difference on the first postoperative day. Only the adhesive-treated subject showed crusting due to adhesion on the wound (Figure 4). No flap necrosis and wound infection were detected.

It was observed that more exudate was accumulated in the distal flap in the subject to which adhesive had been applied on the $4^{\text {th }}$ postoperative day. The majority of PDS sutures were found to have disappeared (Figure 5). There was no infection.

On the postoperative $8^{\text {th }}$ day, all exudates had disappeared, and wound healing had started in both groups. In some subjects of the suture and adhesive groups, partial necrosis was observed in the distal unilateral or bilateral flaps. All PDS sutures were lost. No infection was observed (Figure 6).

All wounds were healed on the $16^{\text {th }}$ postoperative day. No macroscopic difference was observed (Figure 7). 


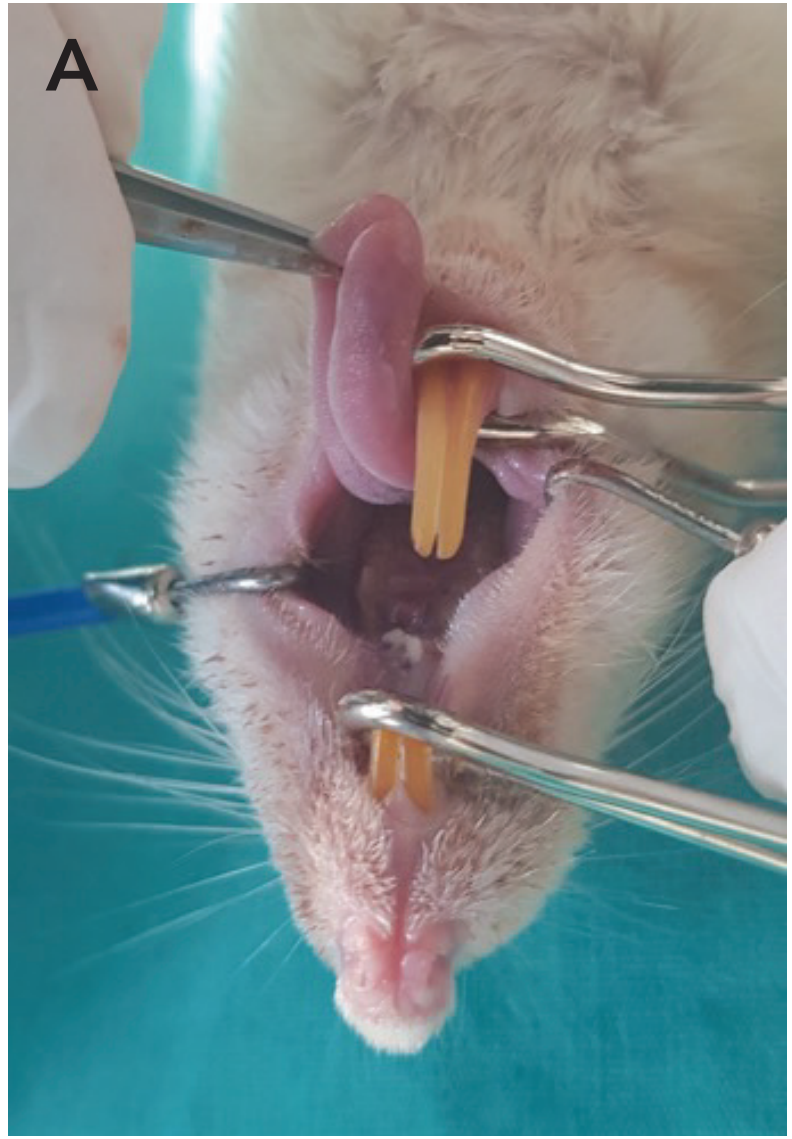

Figure 4: Postoperative $1^{\text {st }}$ day (A) Suture, (B) Adhesive

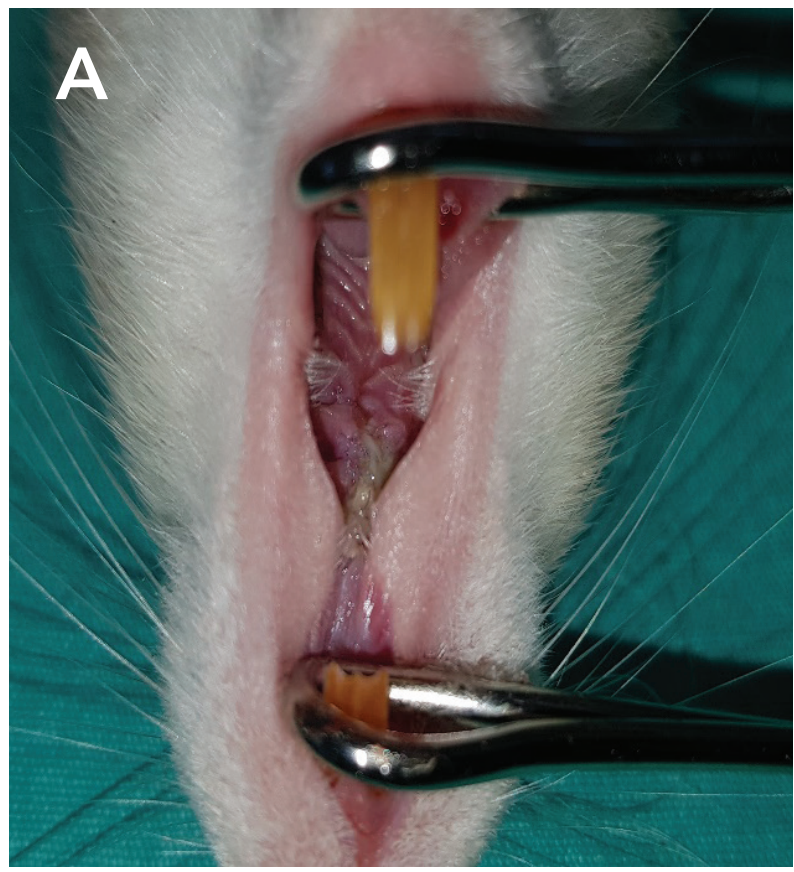

Figure 5: Postoperative $4^{\text {th }}$ day (A) Suture, (B) Adhesive
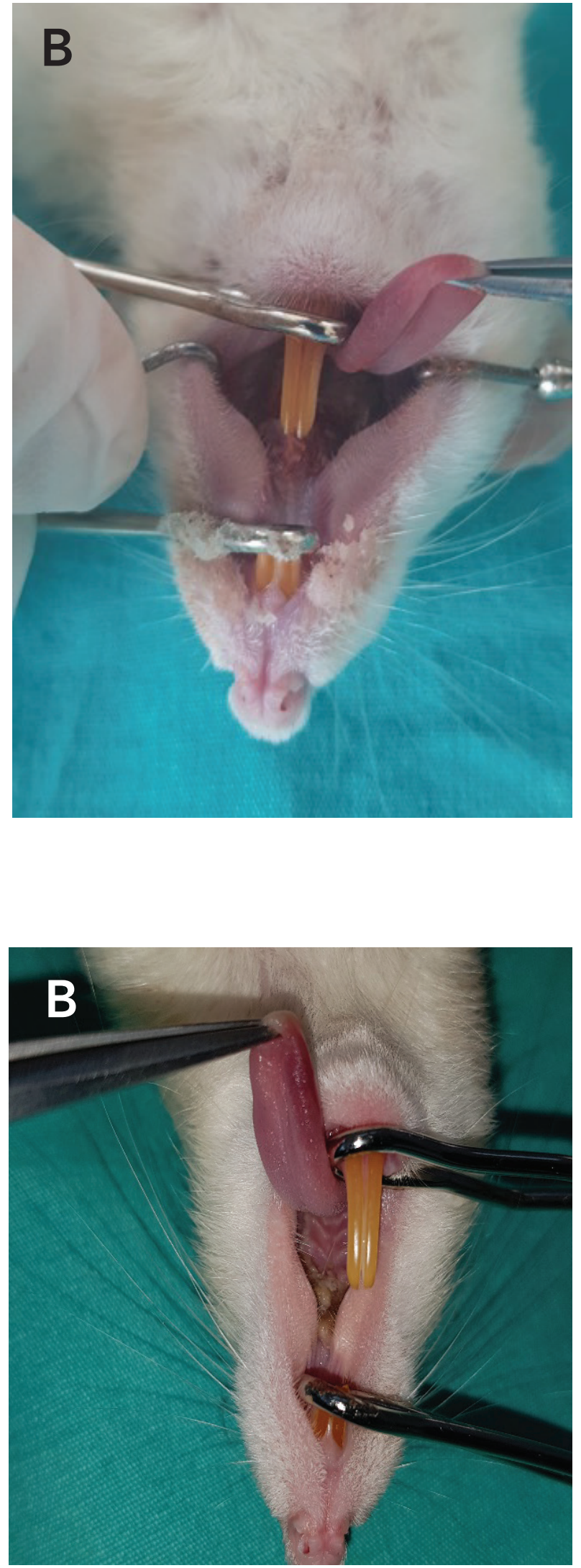


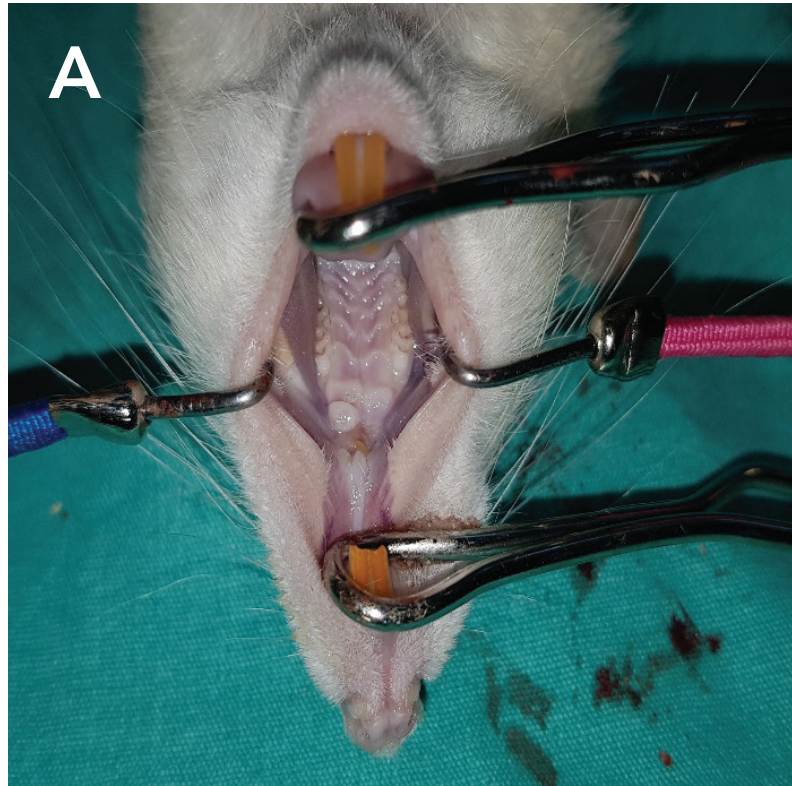

Figure 6: Postoperative $8^{\text {th }}$ day (A) Suture, (B) Adhesive

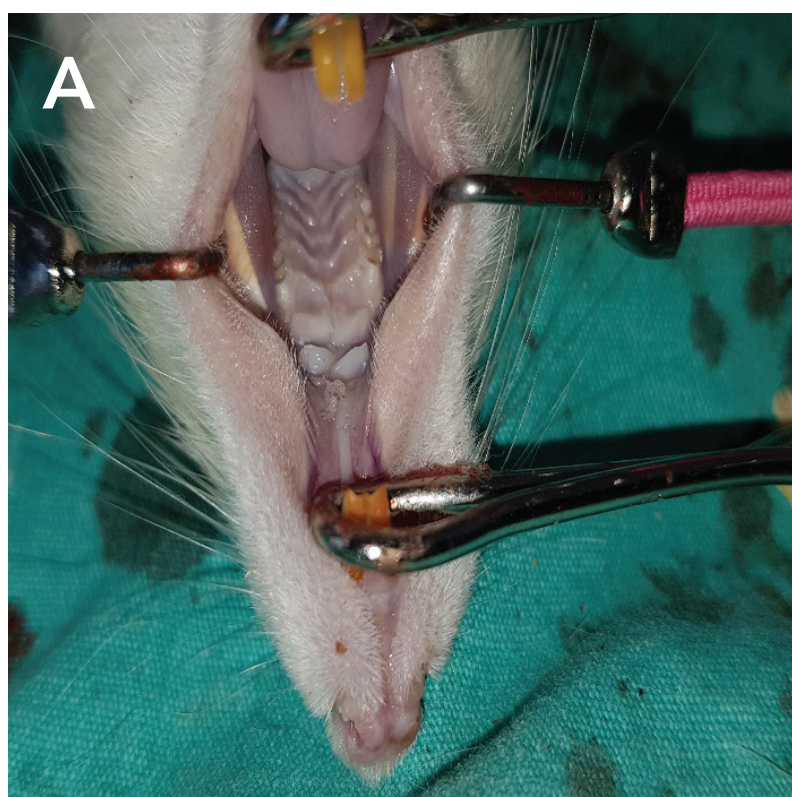

Figure 7: Postoperative $16^{\text {th }}$ day (A) Suture, (B) Adhesive

\section{Histopathological results}

Sections taken from the palate were evaluated histopathologically in terms of inflammation, vascularization and fibroblastic activities. Histopathological evaluation was scored numerically. The results are summarized in Table 1, Table 2, and Table 3.

Wound granulation tissue, inflammation, increased vascularization, fibrous fusion and epithelial regeneration were examined by hematoxylin-eosin staining. Collagen synthesis was examined by masson trichrome staining (Figure 8).
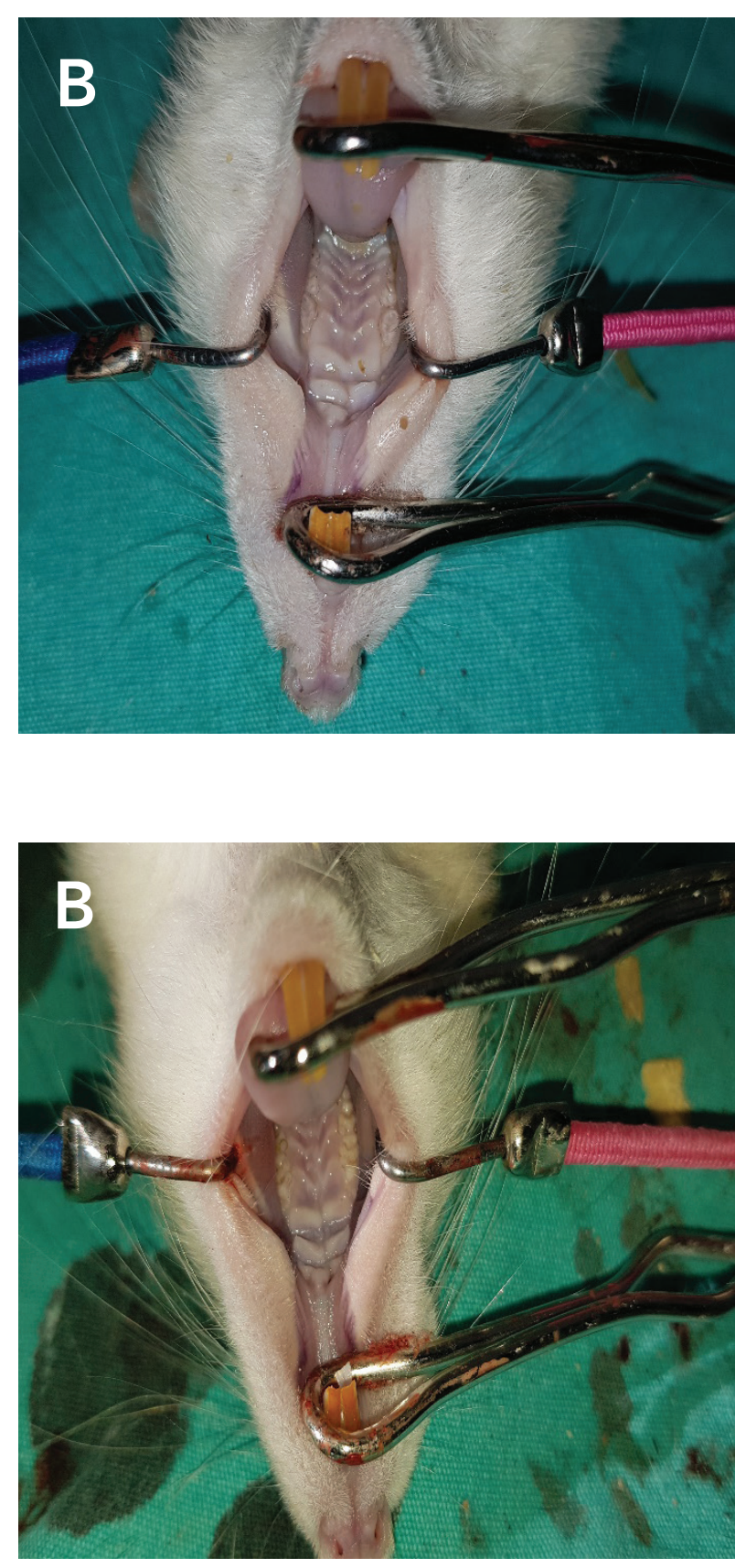

Inflammatory granulation appearance was taken at 40x magnification on the $8^{\text {th }}$ postoperative day (Figure 9). In the suture group, on the $8^{\text {th }}$ postoperative day, vascular rich granulation tissue formation and epithelial generation appearance were taken at 10x magnification with Hematoxylin Eosin staining (Figure 10). On postoperative day 16 , fibrous junction at the sutured repaired incision and epithelial regeneration in adhesive-bonded tissue was achieved at 10x magnification with Hematoxylin Eosin stain (Figure 11). 
Table 1: Inflammatory cell infiltration (Histopathological results)

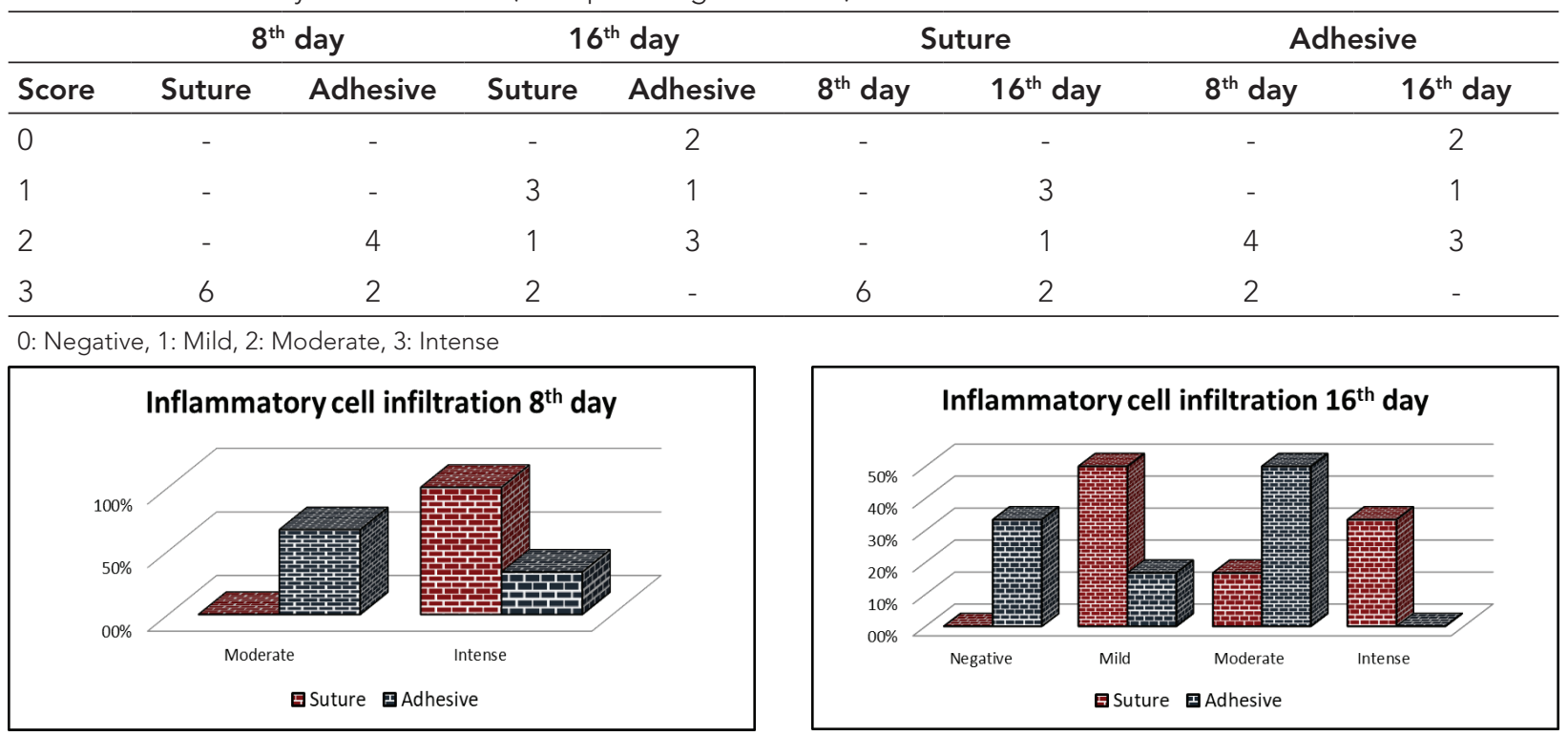

Table 2: Evaluation of vascularity (Histopathological results)

\begin{tabular}{|c|c|c|c|c|c|c|c|c|}
\hline \multirow{2}{*}{ Score } & \multicolumn{2}{|c|}{$8^{\text {th }}$ day } & \multicolumn{2}{|c|}{$16^{\text {th }}$ day } & \multicolumn{2}{|c|}{ Suture } & \multicolumn{2}{|c|}{ Adhesive } \\
\hline & Suture & Adhesive & Suture & Adhesive & $8^{\text {th }}$ day & $16^{\text {th }}$ day & $8^{\text {th }}$ day & $16^{\text {th }}$ day \\
\hline 0 & - & - & - & - & - & - & - & - \\
\hline 1 & 3 & 5 & 4 & 6 & 3 & 4 & 5 & 6 \\
\hline 2 & 3 & 1 & 2 & - & 3 & 2 & 1 & - \\
\hline \multicolumn{9}{|c|}{0 : Insufficient, 1: Sufficient, 2: Rich } \\
\hline \multicolumn{5}{|c|}{ Evaluation of vascularity $8^{\text {th }}$ day } & \multicolumn{4}{|c|}{ Evaluation of vascularity $16^{\text {th }}$ day } \\
\hline
\end{tabular}

Table 3: Evaluation of fibroblastic activity (Histopathological results)

\begin{tabular}{|c|c|c|c|c|c|c|c|c|}
\hline \multirow[b]{2}{*}{ Score } & \multicolumn{2}{|c|}{$8^{\text {th }}$ day } & \multicolumn{2}{|c|}{$16^{\text {th }}$ day } & \multicolumn{2}{|c|}{ Suture } & \multicolumn{2}{|c|}{ Adhesive } \\
\hline & Suture & Adhesive & Suture & Adhesive & $8^{\text {th }}$ day & $16^{\text {th }}$ day & $8^{\text {th }}$ day & $16^{\text {th }}$ day \\
\hline 0 & 2 & - & - & - & 2 & - & - & - \\
\hline 1 & - & 2 & - & - & - & 2 & - & - \\
\hline 2 & 4 & 4 & 5 & 1 & 4 & 5 & 4 & 1 \\
\hline 3 & - & - & 1 & 5 & - & 1 & - & 5 \\
\hline
\end{tabular}



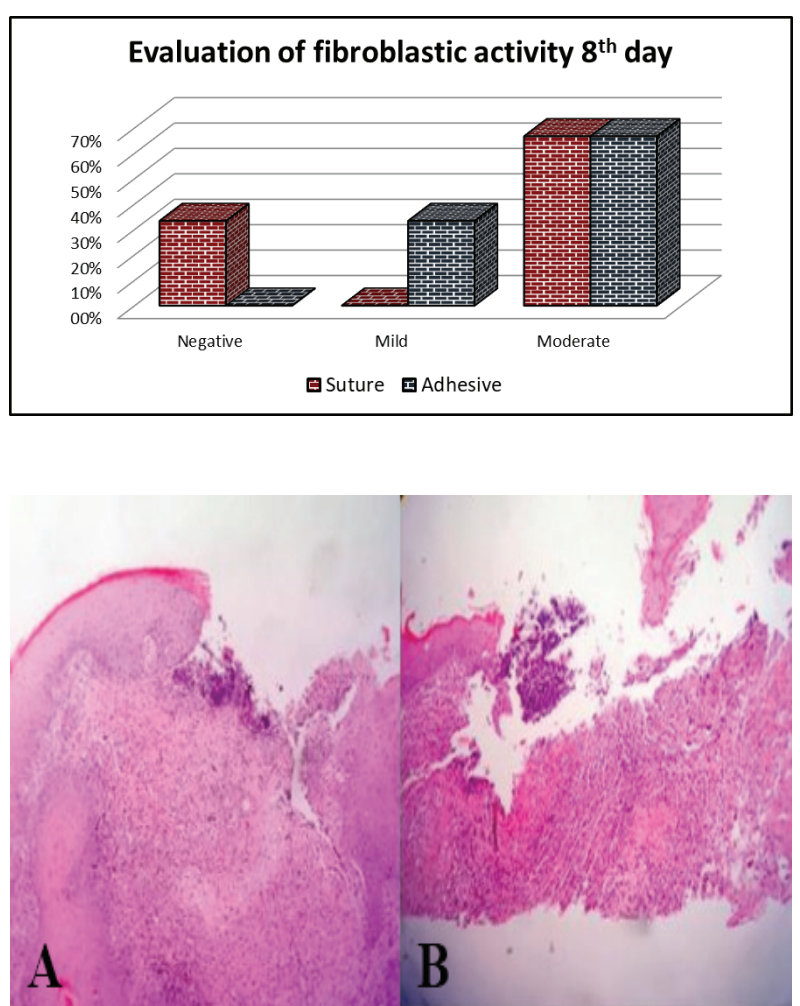

Figure 8: Inflammatory granulation tissue on the postoperative $8^{\text {th }}$ day (A) Suture, (B) Adhesive

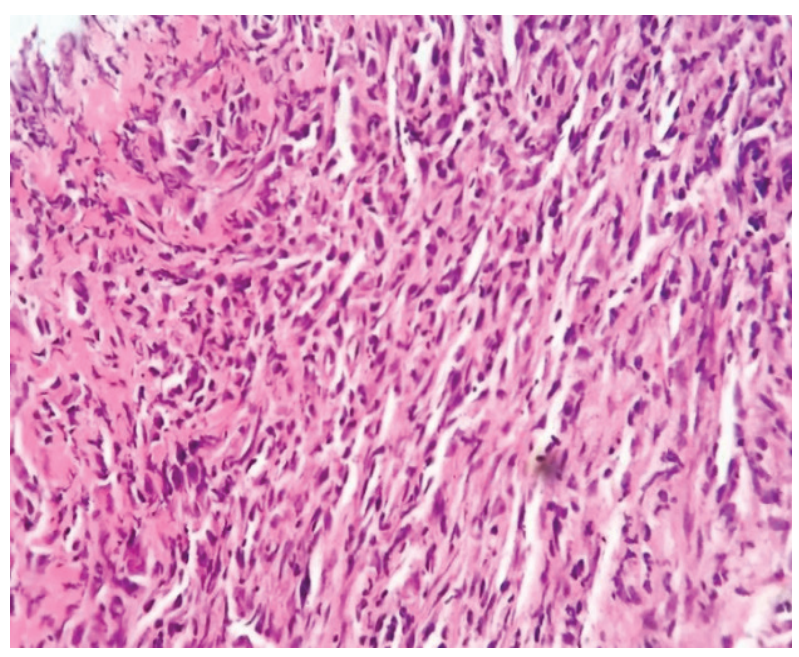

Figure 9: Inflammatory granulation tissue on the postoperative $8^{\text {th }}$ day in the suture group at $40 x$ magnification

On the $8^{\text {th }}$ day, bacteria were observed in some selected suture group subjects (Figure 12). Bacterial colonization was observed in the wound on day 16 (Figure 13). Masson trichrome staining was used to display sufficient subepithelial collagen synthesis at 20x magnification (Figure 14).
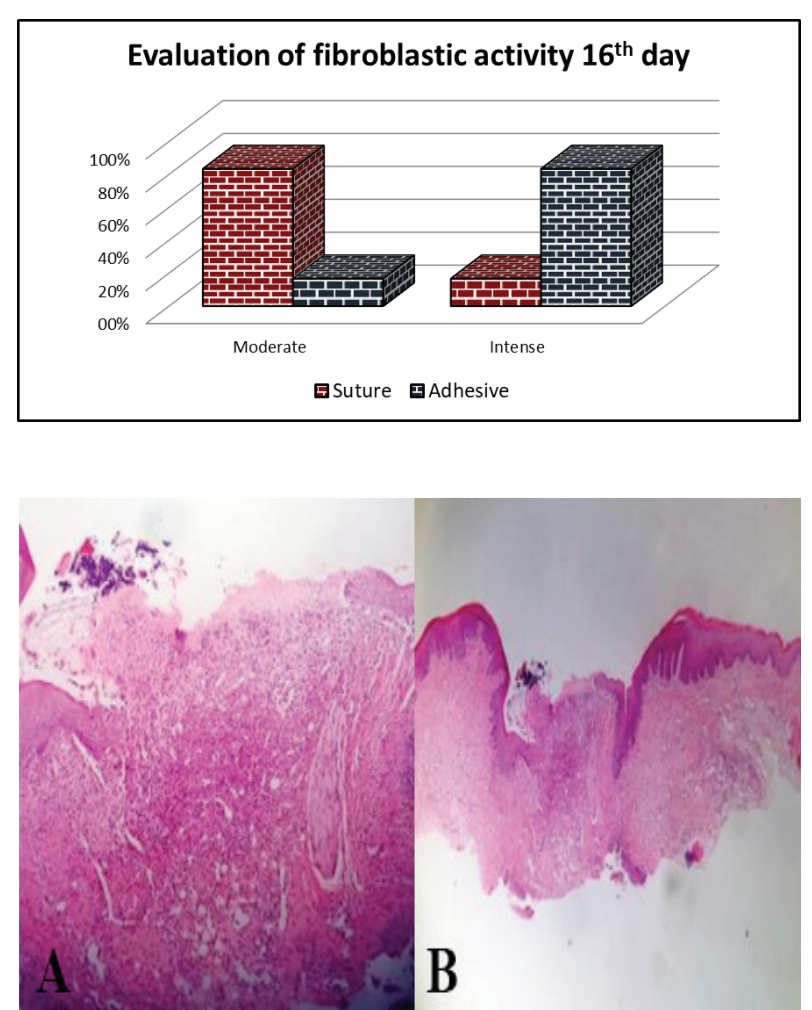

Figure 10: Vascular rich granulation tissue formation in the suture group on postoperative $8^{\text {th }}$ day (A) Vascular rich granulation tissue (B) Epithelial regeneration

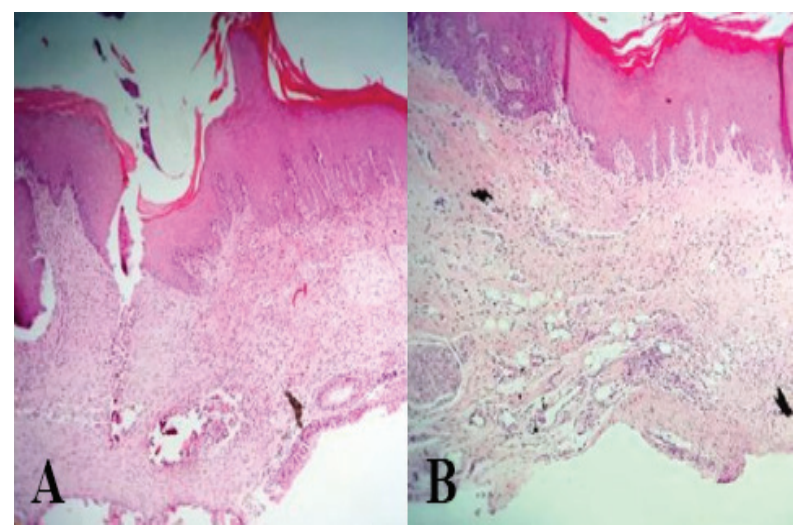

Figure 11: Fibrous junction at the repaired incision site at postoperative $16^{\text {th }}$ day (A) Suture, (B) Adhesive

In the suture group, inflammatory cell infiltration was found to be significantly higher on the $8^{\text {th }}$ day compared to the adhesive group $(p<0.05)$. Inflammatory cell infiltration at day 16 did not differ significantly between the suture and adhesive groups ( $p>0.05$ ) (Table 4).

In the suture and the adhesive group, assessment of the vascularity on the $8^{\text {th }}$ day did not reveal any significant difference $(p>0.05)$. It was the same on the $16^{\text {th }}$ day $(p>0.05)$ (Table 5). 


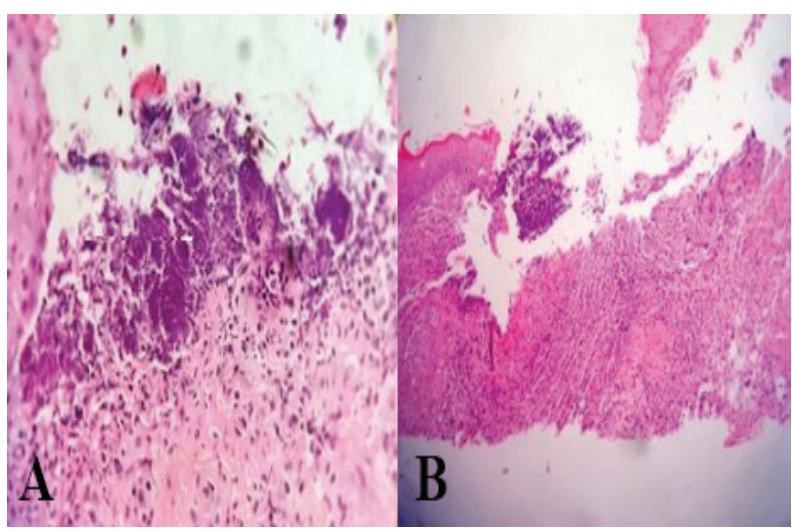

Figure 12: Fibrin exudate and bacterial colonies on the postoperative $8^{\text {th }}$ day (A) Adhesive, (B) Suture

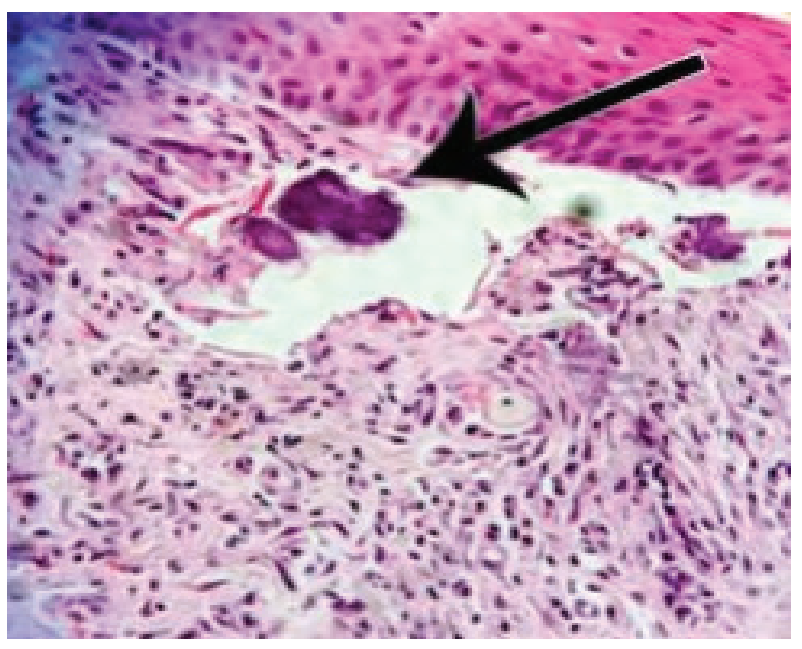

Figure 13: Bacterial colonies in inflammation

Fibroblastic activity on the $8^{\text {th }}$ day in the suture and adhesive groups did not differ significantly ( $p>0.05)$. The fibroblastic activity was significantly lower in the su-

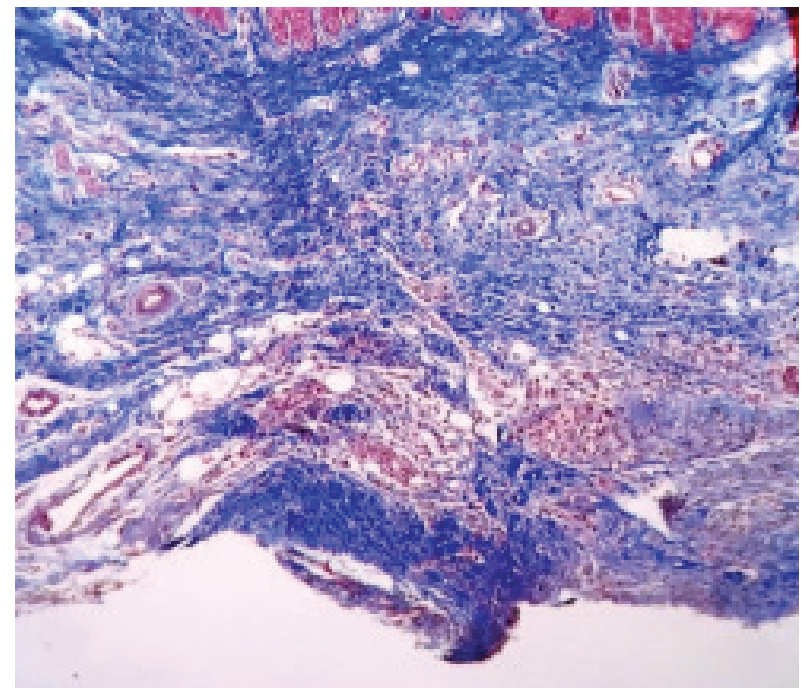

Figure 14: Subepithelial sufficient collagen synthesis

ture group on day 16 compared to the adhesive group $(\mathrm{p}<0.05)$ (Table 6).

\section{DISCUSSION}

Cleft palate is a disorder caused by the fusion problem of bones and soft tissues which separate the oral and nasal cavities. In a surgical approach, it is necessary to avoid traumatizing tissues during the correction of the anatomic deformities in the palate, and to protect the muscle and mucosa as much as possible.

One of the most important points in the surgical treatment of cleft palates is the fixation of mucosal flaps in the midline. In particular, it is necessary to suture the flaps in a way that is not taut and combine the flaps without damaging their edges.

Table 4: Inflammatory cell infiltration $8^{\text {th }}$ day and $16^{\text {th }}$ day

\begin{tabular}{|c|c|c|c|c|c|c|c|c|}
\hline & & \multicolumn{3}{|c|}{ Suture } & \multicolumn{3}{|c|}{ Adhesive } & \multirow{2}{*}{$p$} \\
\hline & & Av & $n-\%$ & Median & Avr & $n-\%$ & Median & \\
\hline \multirow[t]{3}{*}{$8^{\text {th }}$ day } & & & & 3,0 & & & 2,0 & $0,019 \mathrm{~m}$ \\
\hline & Moderate & 0 & $0,0 \%$ & & 4 & $66,7 \%$ & & \\
\hline & Intense & 6 & $100 \%$ & & 2 & $33,3 \%$ & & \\
\hline \multirow[t]{5}{*}{$16^{\text {th }}$ day } & & \multicolumn{2}{|c|}{$1,8 \pm 1,0$} & 1,5 & \multicolumn{2}{|c|}{$1,2 \pm 1,0$} & 1,5 & $0,317^{m}$ \\
\hline & Negative & 0 & $0,0 \%$ & & 2 & $33,3 \%$ & & \\
\hline & Mild & 3 & $50,0 \%$ & & 1 & $16,7 \%$ & & \\
\hline & Moderate & 1 & $16,7 \%$ & & 3 & $50,0 \%$ & & \\
\hline & Intense & 2 & $33,3 \%$ & & 0 & $0,0 \%$ & & \\
\hline
\end{tabular}

m Mann-whitney u test 
Table 5: Evaluation of vascularity $8^{\text {th }}$ day and $16^{\text {th }}$ day

\begin{tabular}{|c|c|c|c|c|c|c|c|c|}
\hline & & \multicolumn{3}{|c|}{ Suture } & \multicolumn{3}{|c|}{ Adhesive } & \multirow{2}{*}{$\mathrm{p}$} \\
\hline & & Avr & $n-\%$ & Median & Avr & $n-\%$ & Median & \\
\hline \multirow[t]{3}{*}{$8^{\text {th }}$ day } & & & & 1,5 & & & 1,0 & $0,241 \mathrm{~m}$ \\
\hline & Sufficient & 3 & $50 \%$ & & 5 & $83,3 \%$ & & \\
\hline & Rich & 3 & $50 \%$ & & 1 & $16,7 \%$ & & \\
\hline \multirow[t]{3}{*}{$16^{\text {th }}$ day } & & \multicolumn{2}{|c|}{$1,3 \pm 0,5$} & 1,0 & \multicolumn{2}{|c|}{$1,0 \pm 0,0$} & 1,0 & $0,138^{m}$ \\
\hline & Sufficient & 4 & $66,7 \%$ & & 6 & $100 \%$ & & \\
\hline & Rich & 2 & $33,3 \%$ & & 0 & $0,0 \%$ & & \\
\hline
\end{tabular}

m Mann-whitney u test

Table 6: Evaluation of fibroblastic activity $8^{\text {th }}$ day and $16^{\text {th }}$ day

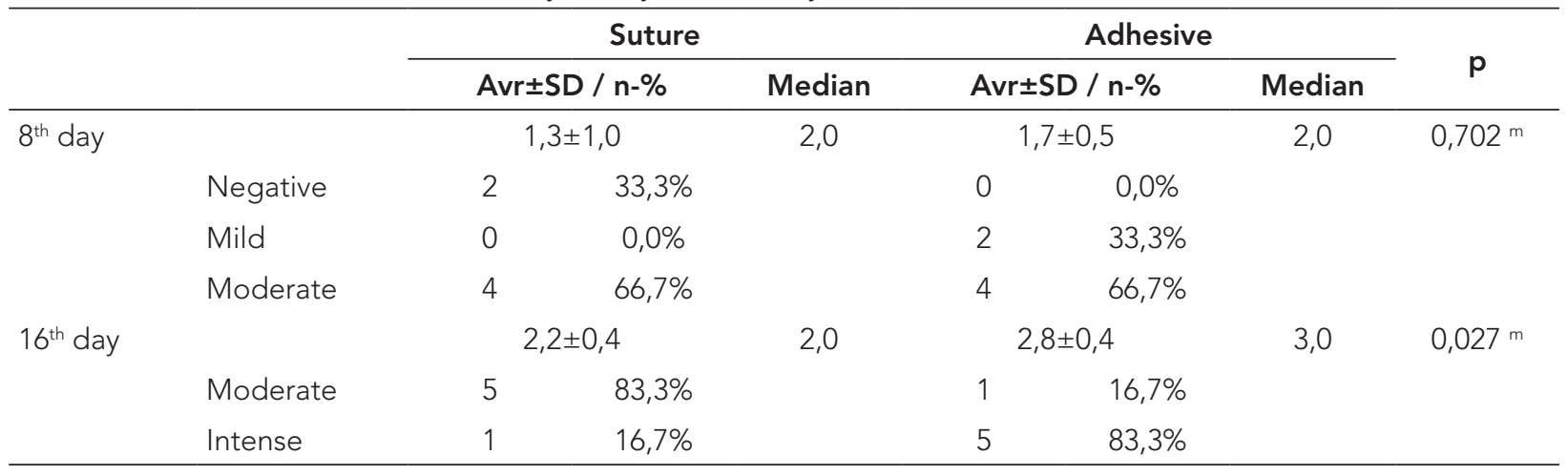

m Mann-whitney u test

The presence and development of strong adhesive effects of cyanoacrylates have become an alternative to conventional treatment methods in many surgical fields.

$\mathrm{N}$-butyl-2-cyanoacrylate is a good biological tissue adhesive due to its bacteriostatic, biodegradable, hemostatic, strong adhesive properties and tissue compatibility. The reason for choosing $\mathrm{N}$-butyl-2-cyanoacrylate in our study is that it has strong bonding properties and good tissue compatibility in non-dry environments.

There is limited research in the literature about the use of N-butyl-2-cyanoacrylate in palate surgery. Öztürk et al. found a decrease in fistula rates in cases where tissue glue was used in cleft palate repair compared to closure with suture material (5). Türkaslan et al. used both suture and tissue glue in 15 cleft palate patients and found no complications during the postoperative follow-up period (6). In our study, unlike in the clinical trials, in order to compare the improvement in cleft palate surgery, in one group only glue was used and the other group only suturing was performed. Subsequently, the wound then healing was examined histopathologically and numerical data were generated.

In a study by Kumar et al. 2013, the effects of silk suture and N-butyl-2-cyanoacrylate on wound healing in the hu- man oral mucosa were compared histopathologically and showed less inflammation in the adhesive used group on day seven (7). In this study by Kumar et al., it was seen that the intensity of inflammation was higher in the early period in the group in which suturing was used.

In our study, the severity of inflammation was significantly higher on the $8^{\text {th }}$-day in the suture group compared to the adhesive group $(p<0.05)$. The increase in inflammation negatively affected wound healing and fibroblastic collagen activity on day 16 . It was significantly lower in the adhesive group $(p<0.05)$. It was thought that the severity of inflammation in the suture subjects was due to the penetration of foreign bodies and infectious agents into the space between the sutures. The most important feature of N-butyl-2-cyanoacrylate is that it provides a waterproof seal at the wound site. With this feature, it protects against foreign bodies and infectious agents.

Quinn et al. reported in their study that N-butyl-2-cyanoacrylate tissue adhesive has an antibacterial effect, especially against gram (+) bacteria, in vitro. In addition, they reported that the $\mathrm{N}$-butyl-2-cyanoacrylate tissue adhesive can be used several times after initial opening of the container, and that cyanoacrylate forms are not contaminated by microorganisms (8). 
The cytotoxicity, blood compatibility and antimicrobial capacities of biocompatible Glubran ${ }^{\circledR}$ and Glubran ${ }^{2} 2$ tissue adhesives were measured in an in vitro study by Montanaro et al. When these adhesives were diluted, they found that their toxicity was acceptable and that they had a haemostatic effect by reducing the aPTT time. They also found that they did not inhibit bacterial growth, although they did prevent the spread of infection (9).

In our study, when tissue adhesive was applied to the wound, it was observed that it rapidly solidified at the point of contact with blood and provided effective haemostasis. Macroscopic evaluation showed that crusting continued on the first postoperative day. In some subjects with adhesive application, necrosis was observed in the distal mucoperiosteal flaps, similar to those in the sutured subjects. Therefore, it was thought that tissue necrosis was not adhesive-induced but may have been due to surgical technique. Macroscopically, there was no infection at the wound site in either experimental groups.

Macroscopically, there was no infection at the wound site in both experimental groups. However, during the histopathological examination, some subjects in the suture group demonstrated bacteria on the wound surface and within the wound. Bacterial colonies were observed in the surface of the wound in early stage, in a single subject. These findings support the idea that the adhesive reduces bacterial contamination, which is in accordance with the results the previous studies.

The adhesive and mechanical properties of Glubran®2 were tested in an in vitro study by Kull et al. (10). Strong binding ability and the high tensile and shear strength in biological tissues of the polymerized film has been shown by tensile tests. In our study, the palate flaps were fixed that they were not stretched to each other in the middle line in the subjects those had been applied adhesive. The most important problem encountered in the clinical practice of palate surgery is wound formation due to stretch flap closure. As a result of our study, we think that the complications can be reduced when adhesive is used together with the suture material. As we mentioned before, this study is an experimental study. Therefore, the results obtained can be a guide for their clinical practice. In this study also it has been found that the adhesive does not only attach flaps to each other, it has also been observed that it distributes the flaps homogeneously to the environment, fixes the flaps to the base and provides strong bonding. In the postoperative follow-up, flaps remained stable in the midline and no subjects had any wound detachment.

In our study, the rat palate was used to demonstrate the efficacy of N-butyl-2-cyanoacrylate in the palatal surgery. Wijdeveld et al. and in de Braekt et al. examined wound healing in Beagle dog palates and produced only mucosal defects without creating bone defects in the midline of the palate $(11,12)$. In another similar study, a similar cleft palate model was established in the rat palate. In this study, it has been investigated whether hyaluronic acid has an effect on maxilla development by reducing scar formation following cleft palate surgery (13). In our study, we created a cleft palate model similar to the previous studies. The aim of our study is not to repair the cleft palate but to show the effectiveness of tissue glue on the palate mucosa, although it does not exactly resemble the cases encountered in daily practice.

$\mathrm{N}$-butyl-2-cyanoacrylate seems advantageous for the surgeon due to shortened operation time and its strong adhesive properties. Moreover, it provides haemostasis and has no tissue toxicity.

As a result of our study, successful results were obtained in combining the mucoperiosteal flaps with N-butyl-2-cyanoacrylate (Glubran $\circledast 2)$ in rat palate. These results were evaluated statistically. In addition, there are findings that $\mathrm{N}$-butyl-2-cyanoacrylate reduces complications such as foreign body reaction, granulation tissue formation, tissue necrosis and infection in rats.

The positive results obtained in our study do not show that tissue glue can only be used in the midline fixation of the flaps in the cleft palate. Another common condition seen in the palate is fistula formation. It is mostly seen as a secondary deformity. Surgical repair is difficult due to scarring of surrounding tissues and narrow and deep surgical area. Those require more sensitivity during surgery. For these reasons, it is thought that tissue adhesive may be an alternative to suture materials in palatal fistula repair.

As a result, it is thought that $\mathrm{N}$-butyl-2-cyanoacrylate, which is used as a surgical tissue glue, is thought to be an alternative method for using together with suture materials because of its easy application, effectiveness and low complication rate in cleft palate operations and in fixation of the mucoperiosteal flaps in cleft palate operations in narrow surgical areas.

Ethics Committee Approval: This study was approved by the Local Ethics Committee of Animal Experiments of Uludağ University (Date:08.02.2018, No:2018-02/02).

Peer Review: Externally peer-reviewed.

Author Contributions: Conception/Design of Study- F.K., S.Ö.; Data Acquisition- F.K., S.Ö.; Data Analysis/Interpretation- F.K., S.Ö.; Drafting Manuscript- F.K., S.Ö.; Critical Revision of Manuscript- F.K., S.Ö.; Final Approval and Accountability- F.K., S.Ö.

Conflict of Interest: Authors declared no conflict of interest.

Financial Disclosure: This work was supported by the Uludağ University Scientific Research Project. Project No: 2191 
Etik Komite Onayı: Bu çalışma için etik komite onayı Bu çalışma Uludağ Üniversitesi Yerel Hayvan Deneyleri Etik Kurulu'ndan alınmıştır (Tarih:08.02.2018, Sayı:2018-02/02).

Hakem Değerlendirmesi: Dış bağımsız.

Yazar Katkıları: Çalışma Konsepti/Tasarım- F.K., S.Ö.; Veri Toplama- F.K., S.Ö.; Veri Analizi/Yorumlama- F.K., S.Ö.; Yazı TaslağıF.K., S.Ö.; Iç̧eriğin Eleştirel İncelemesi- F.K., S.Ö.; Son Onay ve Sorumluluk- F.K., S.Ö.

Çıkar Çatışması: Yazarlar çıkar çatışması beyan etmemişlerdir.

Finansal Destek: Bu çalışma Uludağ Üniversitesi Bilimsel Araştırma Projesi tarafından desteklenmiştir. Proje No: 2191

\section{REFERENCES}

1. Levi B, Brugman S, Wong WW, Grova M, Longaker MT, Wan DC. Palatogenesis: Engineering, pathways and pathologies. Organogenesis 2011;7(4):242-54. [CrossRef]

2. Kosowski TR, Weathers WM, Wolfswinkel EM, Al. E. Cleft palate. Semin Plast Surg. 2009;26(4):164-9. [CrossRef]

3. Hwang K, Lee JH, Kim YJ, Le S II. Palatoplasty: Suturing the mucoperiosteal flaps to the hard palate through hole. J Craniofac Surg 2009;20(3):916-7. [CrossRef]

4. Vastani A, Maria A. Healing of intraoral wounds closed using silk sutures and isoamyl 2-cyanoacrylate glue: A comparative clinical and histologic study. J Oral Maxillofac Surg 2013;71(2):241-8. [CrossRef]

5. Öztürk H, Öztürk H, Duran H, Okur H. The Use of Glubran 2 in Management of Cleft Palate. Düzce Tıp Fakültesi Derg 2008;3:29-31.
6. Turkaslan T, Ozcan H, Dayicioglu D, Ozsoy Z. Use of adhesives in cleft palate surgery:a new flap fixation technique. J Craniofac Surg 2005;4:719-22. [CrossRef]

7. Kumar MS, Natta S, Shankar G, Reddy SHK, Visalakshi D, Seshiah G V. Comparison between Silk Sutures and Cyanoacrylate Adhesive in Human Mucosa- A Clinical and Histological Study. J Int oral Health 2013;5(5):95-100.

8. Quinn JV, Osmond MH, Yurack JA, Moir PJ. N-2butylcyanoacrylate: risk of bacterial contamination with an appraisal of its antimicrobial effects. J Emerg Med 1995;13(4):581-5. [CrossRef]

9. Montanaro L, Arciola CR, Cenni E, Ciapetti G, Savioli F, Filippini F, et al. Cytotoxicity, blood compatibility and antimicrobial activity of two cyanoacrylate glues for surgical use. Biomaterials 2000;22(1):59-66. [CrossRef]

10. Kull S, Martinelli I, Briganti E, Losi P, Spiller D, Tonlorenzi S, et al. Glubran®2 Surgical Glue: In Vitro Evaluation of Adhesive and Mechanical Properties. J Surg Res 2009;157(1):e15-21. [CrossRef]

11. Wijdeveld MGMM, Maltha JC, Grupping EM, De Jonge J, Kuijpers-Jagtman AM. A histological study of tissue response to simulated cleft palate surgery at different ages in Beagle dogs. Arch Oral Biol 1991;36(11):837-43. [CrossRef]

12. In de Braekt MMH, Alphen FAM V, Kuijpers-Jagtman AM, Maltha JC. Wound Healing and Wound Contraction After Palatal Surgery and Implantation of Poly-(L-Lactic) Acid Membranes in Beagle Dogs. J Oral Maxillofac Surg 1992;50:359-64. [CrossRef]

13. Gökmen Z, MD. Effects of Hyaluronic Acid After the Cleft Palate Operation on the Growth of Maxilla in a Rat Model Cleft. Uludağ University, Department of Plastic Reconstructive and Aesthetic Surgery Aesthetic Surgery, Master Thesis. Uludağ University; 2012. 